\title{
Da ruptura ao exílio: o confronto político entre Getúlio Vargas e Flores da Cunha em perspectiva (1935-1937) ${ }^{1}$
}

From the rupture to the exile: the political confrontation between Getúlio Vargas and Flores da Cunha in Perspective (1935-1937)

\author{
Rafael Saraiva Lapuente
}

\begin{abstract}
Resumo
O presente trabalho procura analisar o processo de ruptura política entre Getúlio Vargas e o governador gaúcho José Antônio Flores da Cunha, ocorrido em 1935, e o posterior confronto entre ambos até 1937, quando Vargas consegue isolar política e militarmente Flores da Cunha, obrigando-o a renunciar e a se exilar no Uruguai. Sua queda do governo estadual foi a última barreira vencida por Vargas para a decretação do Estado Novo, o que faria duas semanas após sua renúncia.
\end{abstract}

Palavras-chave: Cultura política. Flores da Cunha. Getúlio Vargas.

\begin{abstract}
This paper analyzes the political rupture process between Vargas and the Governor Jose Antonio Flores da Cunha, which occurred in 1935, and the subsequent clash between the two until 1937, when Vargas can isolate politically and militarily Flores da Cunha, forcing this to resign and go into exile in Uruguay. His fall from the state government was the last hurdle won by Vargas to the enactment of the New State, which would make two weeks after his resignation.
\end{abstract}

Keywords: Political Culture; Flores da Cunha; Getúlio Vargas.

\section{Introdução}

O objetivo central deste artigo é analisar como ocorreu o cerco político ao governador do Rio Grande do Sul, General José Antônio Flores da Cunha, que acabou culminando em sua fuga ao Uruguai, dias antes da decretação do Estado Novo por Getúlio Vargas, onde ficaria exilado até 1942. Acreditamos que o conflito político aqui descrito faz parte da cultura política do Rio Grande do Sul, que foi marcada por intensa

\footnotetext{
${ }^{1}$ Este trabalho surgiu em função do seminário "Deslocamentos, história e Cultura Política: movimentos sociais, legislações restritivas e perseguições (presos) políticos no século XX”, sob a coordenação do Prof. Dr. Leandro Pereira Gonçalves, ao qual agradeço pelo estímulo a produzir este texto. Agradeço também ao Prof. Dr. René E. Gertz pela orientação desta pesquisa, publicada parcialmente aqui.

* Doutorando em História pela Pontifícia Universidade Católica do Rio Grande do Sul (PUC-RS). Mestre em História das sociedades ibero-americanas pela Pontifícia Universidade Católica do Rio Grande do Sul (PUC-RS). Bolsista da Coordenação de Aperfeiçoamento de Pessoal de Nível Superior (CAPES). E-mail: rafael.lapuente@acad.pucrs.br.
} 
bipolarização desde a queda da monarquia, e palco de duas guerras civis por motivos político-partidários e, posteriormente ao período que iremos analisar, seguiu fragmentada, na qual jamais um grupo político conquistou uma hegemonia duradoura, o que confirma a assertiva de Marcelo Baquero e Jussara Reis Prá (2007) de que a menos que amplas rupturas históricas obriguem os grupos sociais a realizarem uma remodelação, a cultura política continuará a reproduzir-se conforme as matrizes originais, afinal não se pode negar o efeito dos fatores históricos de formatação e desenvolvimento de valores, atitudes e comportamentos em relação à política. Dessa forma, temos de levar em consideração que "[...] as transformações pelas quais passou a estrutura socioeconômica gaúcha após 1930 e depois de 1950 não provocaram alterações substanciais na estrutura de poder que vigorara até então.”

Cremos que a cultura política gaúcha está inserida numa série de culturas políticas existentes no Brasil daquele momento, afinal, “[...] é evidente que no interior de uma nação existe uma pluralidade de culturas políticas, mas com zonas de abrangência que correspondem à área de valores partilhados [...]” (BERSTEIN, 1998), que se encontra multifacetada nas particularidades regionais daquele período, em um momento de transição entre aquilo que representava a República Velha e as mudanças advindas da Revolução de 1930.

Tradicionalmente, a política estadual na Primeira República estava dividida em, de um lado, os republicanos, arregimentados no Partido Republicano Rio grandense (PRR) e, do outro, os federalistas, agrupados no Partido Federalista (PF), que fundariam, junto aos republicanos dissidentes, uma nova agremiação, o Partido Libertador. Entretanto, mesmo com a predominância do PRR, esse sempre se manteve em embates políticos e armados com o Partido Federalista, ligado à região da Campanha $^{2}$ e de caráter mais conservador, economicamente vinculado à produção pecuária.

Desse modo, o Rio Grande do Sul possuía duas correntes políticas em disputa, até 1927, quando a eleição de Getúlio Vargas para presidente do estado viabilizou a unificação dos partidos do estado em uma coligação, denominada Frente Única Gaúcha, afastando Borges de Medeiros da presidência do estado após 25 anos, assim

\footnotetext{
${ }^{2}$ A região da Campanha é a região do Rio Grande do Sul que faz fronteira com Uruguai e parte da fronteira gaúcha com a Argentina. Entre outros municípios, ela abrange Uruguaiana, Alegrete, Quaraí, Santana do Livramento e Bagé. Sobre a região da Campanha, cf. SILVA, Marco Antônio Medeiros da. Qual é o jogo? Um inventário dos discursos sobre a estrutura socioeconômica da campanha riograndense. Porto Alegre: FCM Editora, 2014.
} 
permanecendo durante a campanha da Aliança Liberal, quando o Rio Grande do Sul era o único estado no país em que possuía um candidato de consenso, fator tão admirável pela trajetória política de conflitos que acabou ficando conhecido como o "milagre do Rio Grande do Sul". ${ }^{3}$ Todavia, o milagre teve duração efêmera, até 1932, quando Frente Única Gaúcha (FUG) se lançou em apoio aos paulistas, mas sem a adesão de Flores da Cunha, então interventor do Rio Grande do Sul. Esse novo choque altera o contexto político no estado, levando o PRR pela primeira vez na oposição e acompanhado pelo PL, força o situacionismo a fundar um novo partido.

A cultura política neste trabalho é interpretada como "[...] um conjunto de valores, tradições, práticas e representações políticas partilhadas por determinado grupo humano, que expressa uma identidade coletiva e fornecem leituras comuns do passado, assim como fornece inspiração para projetos políticos direcionados ao futuro" (MOTTA, 2014, p. 21), como também levamos em consideração a assertiva de Karl Rohe (2010, p. 3-4), que compreende cultura política como “[...] um contexto carregado de referências de sentido, dentro do qual transcorre a prática de vida política de atores que agem, pensam e sentem, guiados por interesses".

Compreendendo nossa pesquisa sobre os partidos, recorremos a Rodrigo Patto Sá Motta (1999), que define um partido político como um agrupamento de pessoas que tendem a conquistar e a preservar o poder. Além dele, nos parece igualmente válida a reflexão de Serge Berstein (2003), quando afirma que

\footnotetext{
Para que nasça um novo partido, é necessário além disso que, no interior do movimento evolutivo constatado, se produza uma crise, uma ruptura bastante profunda para justificar a emergência de organizações que, diante dela, traduzam uma tendência de opinião suficientemente fundamental para durar e criar uma tradição capaz de atravessar o tempo [...]. (BERSTEIN, 2003, p. 67-68).
}

Compreendemos o sistema partidário como o conjunto de relações dos diversos partidos entre si, com os grupos de interesse, por um lado, e com os diversos aparatos que compõem o Estado, por outro, pensando assim em uma organização complexa que se move num espaço de organizações mais ou menos similares (SOUZA, 1990). Procuraremos analisar as divisões políticas no Estado e seus atores envolvidos em um

\footnotetext{
${ }^{3}$ Sobre a unificação, cf. CASTRO, Maria Helena de Magalhães. Rio Grande do Sul no pós-1930: De protagonista a coadjuvante. In: GOMES, Angela de Castro (Org.). Regionalismo e centralização política: Partidos e constituinte nos anos 30. Rio de Janeiro: Nova Fronteira, 1980. O termo milagre do Rio Grande do Sul está em: CORTES, Carlos E. Política gaúcha (1930-1964). Porto Alegre: EDIPUCRS, 2007. A nova geração de políticos, sobretudo os republicanos, foi destacada em: LOVE, Joseph. O Regionalismo Gaúcho e as origens da Revolução de 1930. São Paulo: Perspectiva, 1975.
} 
contexto de disputa pelo poder político, afinal, é impossível fazer essa análise desconexa:

\begin{abstract}
Das determinações externas, das pressões, das solicitações de todo tipo. Foi e continua sendo - uma contribuição das pesquisas das últimas décadas lançar luz sobre o jogo dos interesses, as correspondências entre os pertencimentos sociais e as escolhas políticas, acompanhar a intervenção dos grupos de pressão e mostrar que a decisão política era resultante de uma multiplicidade de fatores que nem todos eram políticos, podendo ir até a alienação da vontade política e o confisco do Estado. (REMOND, 2003, p. 446).
\end{abstract}

Por fim, esclarecido nosso escopo teórico-conceitual, procuraremos demonstrar o processo de isolamento político de Flores da Cunha, em confronto com Vargas, e o papel da Frente Única Gaúcha nesse contexto, bem como a participação de Góis Monteiro na frente militar.

\title{
A política rio-grandense inserida no contexto estadual e federal
}

Com os dois partidos do estado no exílio por apoiar a Guerra Civil de 1932, o situacionismo gaúcho, encabeçado por Flores da Cunha junto de Vargas e Oswaldo Aranha, vê-se acéfalo, fundando o Partido Republicano Liberal, que surge "[...] das cinzas dos velhos partidos gaúchos, exgotados (sic) em sua finalidade, pelo abandono de seus princípios básicos [...]" (PARTIDO REPUBLICANO LIBERAL, 1933, p. 43), nos dizeres de Vargas. Já o interventor gaúcho surge como uma liderança nacional que não se contenta em apenas administrar o Rio Grande do Sul sem interferir na política nacional e de outros estados. É a partir dessa postura 'intrometida' de Flores da Cunha que iniciarão os primeiros dissídios entre os líderes gaúchos, que culminarão em uma "guerra surda" entre ambos, tendo como resultado a renúncia e o exílio de Flores da Cunha em 1937.

Apesar de ser apenas em 1935 que a rivalidade entre Vargas e Flores ganha uma conotação mais aguda, antes algumas distensões entre o líder político do estado e o governo central ocorreram: fazendo uma análise no Diário de Getúlio Vargas, encontramos oito ameaças de renúncia de Flores da Cunha do cargo, desde o fim da revolução de 1932 até 15 de abril de 1935, quando toma posse como governador constitucional. Essa relação de intensa pressão de Flores da Cunha, entretanto, está atrelada a uma colaboração de Flores com Vargas, que possuíam, nesse momento, uma relação bastante amistosa. Afinal, com um Rio Grande dividido e com os principais 
partidos na oposição e conspirando, a presença de Flores era a garantia de ordem política no estado natal do presidente. Verificando seu Diário nesse período, vemos raras críticas a Flores da Cunha, marcando uma relação de confiança mais perceptível ainda quando as ameaças de demissão do cargo de interventor se concretizam e Vargas (1995, p. 173) nega: “[...] respondi não aceitando, por julgar indispensáveis seus serviços."

Essa situação muda após 1935. O poder de Flores da Cunha aumentaria se o pacto federativo abonasse maior autonomia aos estados, enquanto o de Vargas cresceria enquanto a centralização das decisões e dos poderes se concentram no governo federal. Esse vai ser o embate principal entre os dois, buscando ambos o fortalecimento de seus próprios poderes. Deve-se levar em conta também que, se até 1935 Flores da Cunha era um interventor que dependia da lealdade a Getúlio Vargas para se manter no cargo, quando ele é eleito governador constitucional não depende mais dessa premissa, ou seja, o rompimento não culminaria em afastamento do cargo.

Flores da Cunha, em um discurso cerca de 20 anos depois, relatando a perseguição política que sofreu, mencionou o momento quando Vargas se dirigiu ao Palácio Piratini, em agosto de 1935, e disse:

\begin{abstract}
Flores, com esta constituição de 1934 e com esse congresso eu não poderei continuar governando. [...] [Flores responde]: Em outubro haverá outra eleição, você terá uma grande maioria e poderá governar francamente, amparado no poder Legislativo. [...] E desde então começaram as hostilidades a mim, ao meu governo, através da imprensa assalariada a seu serviço e também de alguns beleguins da política que nunca faltam em todas as situações. (BRASIL, 1953, p. 2639). ${ }^{4}$
\end{abstract}

Esse momento, para Flores da Cunha, foi o ponto de inflexão de sua relação com Getúlio. Recorrendo novamente ao Diário de Getúlio Vargas, percebemos que o crescimento das críticas para Flores da Cunha começa um pouco antes, em abril, em função da rivalidade entre Flores da Cunha e Gois Monteiro, uma questão que trouxe dores de cabeça a Getúlio, já que o segundo, no cargo de ministro da guerra, não admitia a manutenção de corpos provisórios, “[...] reserva irregular a serviço de caprichos caudilhescos [...]" (COUTINHO, 1956, p. 190), como Góis descreveu em suas memórias.

\footnotetext{
${ }^{4}$ BRASIL. Congresso Nacional. Câmara dos Deputados. Diário da Câmara dos Deputados. Discurso do deputado Flores da Cunha. Rio de Janeiro. Ano VIII, n. 69, 11.04.1953, p. 2639. Disponível em: <http://imagem.camara.gov.br/Imagem/d/pdf/DCD11ABR1953.pdf\#page=>. Acesso em 25.07.2015.
} 
Quando a candidatura à presidência da república de Góis Monteiro foi lançada pelo Clube 3 de Outubro, o interventor do Rio Grande do Sul convocou os interventores de Minas Gerais, Bahia e Pernambuco, dizendo sustentar a candidatura de Vargas nem que fosse pelas armas. Não satisfeito, ainda mobiliza corpos provisórios no Rio Grande do Sul, provocando a ira de Góis que, na visão de Vargas, levantara o espírito de classe no exército contra Flores da Cunha (VARGAS, 1995). Aqui, fica bastante evidente a tentativa de Getúlio Vargas em contemporizar os ânimos, sem pender imediatamente para nenhum dos lados.

Esse assunto será outro motivo para desgaste da imagem de Flores da Cunha. Quando iniciou os trabalhos da constituinte, Góis lançou um manifesto exigindo autonomia e aumento dos soldos no exército, sofrendo hostilidades do Partido Republicano Liberal (PRL), com a exigência da demissão do general. Góis, não obstante, também realizaria uma campanha aberta contra Flores na imprensa, e, quando retornou a ter maior influência no Catete em 1936, nomeou figuras hostis a Flores da Cunha para chefiar a $3^{a}$ Região Militar. A rivalidade entre os dois só se agravaria como bem definiu o brasilianista Carlos E. Cortés (2007), ambos eram condutores de filosofias inconciliáveis.

Enquanto isso, Flores da Cunha, desde o fim da guerra civil de 1932, procurou reconciliar a política gaúcha. Poucos dias antes de fundar o PRL, ele procurou a FUG no exílio e, por intermédio de Maurício Cardoso, propôs reunificar a política regional sem sucesso. Já após as eleições de 1933, o jornal situacionista A Federação divulgara uma nota intitulada "A generosidade em função da paz" em que abordava:

\begin{abstract}
O general Flores da Cunha continúa firme no proposito de levar a bom termo e o mais depressa possivel a pacificaçao dos espiritos no Rio Grande do Sul. Apezar de todas as dificuldades que os nossos adversários teem oposto e continuam a opor a essa iniciativa, o eminente cidadão persiste no seu generoso proposito. [...] E aí está porque o general Flores da Cunha acaba de renovar o seu ardente desejo de ver repressarem ao Rio Grande, os seus patrícios exilados, com todas as garantias que as exigencias da ordem possam permitir nesse momento. Todavia - é bem de ver esse 'desideratum' não depende, apenas, dele. Por uma circunstância que tem tanto de paradoxal, quanto de explicável - são os próprios beneficiarios da munificencia e da tolerancia oficial, os que se opõem aos seus nobres objetivos. É preciso, portanto, para que se alcance a total da pacificação das conciencias, que haja um movimento simultaneo e de boa vontade; é preciso que aqueles que devem receber venham ao encontro de quem quer dar (BIBLIOTECA NACIONAL, 1933, p. 1). ${ }^{5}$
\end{abstract}

\footnotetext{
${ }^{5}$ BIBLIOTECA NACIONAL. Hemeroteca Digital. A generosidade em função da paz, A Federação, 24.05.1933, p.1.
} 
Fazendo uma análise crítica em cima da publicação do periódico governista, é perceptível uma cobrança pública à Frente Única Gaúcha, com suas principais lideranças exiladas ${ }^{6}$, em compor com o governo estadual uma conciliação, jogando a responsabilidade pela divisão política do estado aos oposicionistas. Um destaque bastante evidente é dado para a iniciativa ter partido de Flores da Cunha, e a Frente Única ter negado maiores conversas com o interventor. Desconsiderando as partes superlativas do texto, que visam engrandecer a figura do interventor em detrimento de uma suposta intransigência da oposição gaúcha, a tentativa de unificar o estado tinha um interesse por trás: formar coesão num estado fracionado e, assim, aumentar o poderio de Flores da Cunha em um Rio Grande unido sob sua liderança.

Quatro dias após a publicação de A Federação, o decreto n. ${ }^{\circ} 24.297$ concedia anistia aos revoltosos de 1932, bandeira essa defendida por Flores desde março de 1933. Os revolucionários gaúchos, retornando, logo começam a tramar contra o PRL (RANGEL, 2001), todavia nunca se abstendo de conversar com os dois políticos gaúchos, mas especialmente com Getúlio Vargas. É curioso notar essa mudança de atitude da FUG que, pouco tempo atrás, pegara em armas para derrubar Getúlio. Isso fica ainda mais claro ao recorrermos, novamente, ao Diário do presidente da república, que relata a procura do líder do Partido Libertador:

Pela manhã do último dia, mandou-me um cartão, com muita insistência para falar-me, o dr. Argemiro Dornelles, meu antigo médico em São Borja, para tratar de assunto importante. Recebi-o. Disse-me que vinha da parte de Raul Pilla, que este havia mudado de opinião a meu respeito, compreendia que não fizera um juízo exato da situação, estava disposto a uma aproximação com o governo federal, e que isto seria fácil, bastaria substituir a candidatura do Flores à presidência do estado. (VARGAS, 1995, p. 344-345).

Em outra passagem, do dia 8 de abril de 1935, é relatado o encontro com o republicano Lindolfo Collor:

À noite, recebi Lindolfo Collor, cuja aproximação se verificou por intermédio
e iniciativa do General Góis. [...]; [Entramos no assunto: A pacificação do
Rio Grande]. Explicou-me as demarches havidas, segundo ele, por iniciativa
e insistência do Flores, e a recusa que havia à aceitação da candidatura do
Flores, que importava uma simples adesão. Observei-lhe que as aspirações
ideológicas da Frente Única que já não estavam realizadas estavam em vias
de realização. Nessas condições, fazer questão do nome do Flores seria
conduzir um assunto que poderia trazer tantos benefícios ao país a uma
questão pessoal. (VARGAS, 1995, p. 378).

${ }^{6}$ Sobre a atuação dos políticos rio-grandenses no exílio, ver: Rafael Saraiva Lapuente (2015). 
Percebe-se novamente uma aproximação da FUG com Vargas, dessa vez por meio de um membro do PRR e intermediado pelo rival de Flores da Cunha, Góis Monteiro, tomando novamente como enclave a figura do interventor como líder da política regional. A conversa entre os dois vai mais além:

Falou-me, então, na hipótese de a pacificação estender-se a todo o país em torno do meu governo, do qual eles fariam parte por uma reorganização do ministério, para realizar um rigoroso programa financeiro. Respondi-lhe que aceitava a discussão da tese e sugeria mais a hipótese de formação de um grande partido nacional, para o qual eles entrariam, e que traçaria um programa político e administrativo que seria rigorosamente executado. Também aceitou, ficou de ouvir seus companheiros e, até mesmo, se fosse necessário, ir ao Rio Grande e depois responder-me. (VARGAS, 1995, p. 378-379).

Vargas não apenas "dá conversa" a Lindolfo Collor, como cogita a possibilidade de criarem um partido em conjunto com a Frente Única Gaúcha, oposição ao governo estadual, e ainda participarem do governo central por intermédio de uma nova recomposição ministerial. Nota-se que, durante essa conversação, Flores e Vargas ainda não estão rompidos. Percebemos uma verdadeira jogatina de mão dupla realizada pelo presidente, sinalizando com os dois lados da política estadual, mantendo todas as portas de contato abertas, visando também a não depender somente de Flores da Cunha para a manutenção da ordem política no estado. Já Flores da Cunha buscava entendimento com a FUG, sem ter um atendimento de forma recíproca, inclusive convidando Raul Pilla para assumir o comando da recém-criada Secretaria da Educação e Saúde Pública em 1935 sem exigir aliança partidária com a FUG ou PL (TRINDADE, 1980). Todavia, o preço pedido pela FUG - retirada da candidatura de Flores da Cunha ao governo estadual - era um preço bastante alto.

Getúlio sabia dos diálogos da FUG com Flores, e tinha conhecimento, também, da resistência que alguns elementos frenteunistas punham para a consolidação da unificação partidária rio-grandense. Batista Lusardo, Maurício Cardoso e Borges de Medeiros são alguns dos nomes mencionados em um telegrama enviado em 23 de março de 1935 por Flores a Vargas como opositores da conciliação política estadual e favoráveis a uma ação violenta (ELÍBIO JR, 2006).

Os dois primeiros embates abertos entre Getúlio e Flores vieram com as eleições estaduais de Santa Catarina e do Rio de Janeiro, os quais mostram que Flores da Cunha 
não era um "federalista", ou seja, não se postava como um defensor da autonomia dos estados, mas apenas do seu reduto político. Quando foi possível, interferiu na política de diversos estados, procurando influenciar a escolha de seus governadores de forma semelhante ao senador Pinheiro Machado na Primeira República, por sinal, seu padrinho político.

Analisemos, portanto, os casos estaduais. Em Santa Catarina, Flores da Cunha tomara partido na campanha do interventor Aristiliano Ramos, que possuía minoria no legislativo. Mesmo com a intervenção de Flores da Cunha e Antunes Maciel, exministro da justiça e membro do PRL, o vencedor foi Nereu Ramos, primo e adversário político de Aristiliano, que possuía o apoio de Getúlio. Mas será a intervenção na eleição do Rio de Janeiro, em setembro, que trará uma frente aberta entre ambos. Nesse período, o Rio de Janeiro é um local estratégico, pela proximidade com a capital do país, e seu controle, em um enfrentamento militar, poderia ser decisivo. Grande parte do imbróglio ocorrido nesse estado foi justamente durante as festividades do centenário farroupilha, período em que Vargas estava no estado para prestigiar o evento. O candidato a governador do estado, apoiado por Flores da Cunha, era Christóvão Barcellos, que controlava 22 deputados e possuía, inclusive, apoio financeiro do chefe político do Rio Grande do Sul. Já os demais 23 deputados, divididos, entraram em consenso para apoiar Protógenes Guimarães, ministro da Marinha e apadrinhado pelo presidente (CORTES, 2007).

Getúlio Vargas, enquanto esteve em Porto Alegre, passou hospedado no Palácio Piratini, sede do governo gaúcho, com seus telegramas interceptados por Flores da Cunha, que divulgara um diálogo do presidente com o ministro da justiça que "comprovaria" a intervenção federal nos assuntos daquele estado. Vai ser em meio a isso que Vargas desabafa:

Os principais motivos de queixa que tenho contra o Flores são os seguintes: $1^{\circ}$ ) O constante trabalho oficial que faz no Rio Grande, dizendo que o governo federal nada fez por aquele estado; $2^{\circ}$ ) A mania de estar, lá de Porto Alegre, pretendendo dirigir a política federal, agitando precipitadamente a questão da sucessão presidencial e intervindo na política de outros estados; $3^{\circ}$ ) Quando estive em Porto Alegre, minha correspondência telegráfica com o Rio era controlada pelo Flores, e, nestas condições, quando os avisos iam pela estação do palácio do governo, seu telegrafista solicitava ao diretor regional as cópias dos telegramas que o almirante Protógenes me dirigia. $4^{\circ}$ ) Apoderando-se, por esta maneira, do telegrama do ministro da Justiça passado a mim, divulgou-o para que fosse publicado. $5^{\circ}$ ) E, por fim, inventou ou admitiu a invencionice de que eu procurava abrir cisão na política do Rio Grande para enfraquecê-lo. (VARGAS, 1995, p. 426).

\footnotetext{
${ }^{7}$ Os autores que, equivocadamente, não fazem essa distinção são Trindade (1980) e Campos (2001).
} 
Em outras palavras, podemos perceber que, a partir da intromissão de Flores na "questão do Rio de Janeiro", Getúlio Vargas acabou estourando com uma série de aborrecimentos que possuía com o governador do Rio Grande do Sul.

\section{A erosão do sistema partidário regional: a divisão como um fator pró-Vargas}

Por meio da porta de diálogo que manteve aberta com a FUG, Vargas receberá, de Raul Pilla, uma proposta referente a uma nova fórmula de governo, em setembro de 1935, denominada "Fórmula Santos-Pilla", que consistiria em uma administração de gabinete, de cunho parlamentarista e que garantiria a participação da oposição no governo. A "Fórmula Santos-Pilla" foi preterida em nível federal, mas Flores da Cunha, que há tempos buscava uma aproximação com a Frente Única Gaúcha, vê nessa recusa uma oportunidade para retomar conversações nesse contexto. Tendo, a essa altura, o rompimento consolidado com Getúlio Vargas, Flores da Cunha se vê ameaçado politicamente. Eis uma conjuntura propícia para unificar e fortalecer o estado, caso o conflito com Getúlio ganhe maiores proporções.

As conversações sobre a unificação estadual, que seria denominada de Modus Vivendi, se intensificam em novembro de 1935, culminando na sua assinatura em janeiro do ano seguinte com ares de muita comemoração na imprensa regional e nacional. Resguardando a autonomia partidária e a liberdade de ação dos três partidos signatários, a aliança se deu através da aprovação de um projeto de lei em que os secretários de estado manteriam suas atuais funções, se reuniriam semanalmente em conselho, sob liderança de um presidente do secretariado nomeado pelo governador, que seria incumbido de escolher os secretários junto ao governador, e fiscalizaria a execução do orçamento. Os secretários de estado seriam subordinados ao poder legislativo. A Assembleia Legislativa estadual ganhou a autonomia de poder convocar qualquer secretário, dentre outras questões de cunho político e administrativo (TRINDADE, 1980).

Não obstante, eram previstas duas secretarias para a Frente Única, uma a ser ocupada pelo libertador Raul Pilla, secretaria da agricultura, e a outra pelo republicano Lindolfo Collor, secretaria da fazenda. Em síntese, o preço que Flores pagaria era a limitação do poder executivo em troca de uma composição política unificada com a oposição, ao menos em tese, mas não totalmente na prática, pois, como observou Elíbio 
Jr (2006), o pacto não incumbiu em "amarrar" as ações do governador como se poderia imaginar com a fórmula de cunho parlamentarista.

Além de ceder duas secretarias para a FUG, tradicionalmente a Brigada Militar fora usada para fins políticos. Ter sua nomeação sob tutela da Frente Única nos municípios em que ela fora majoritária no pleito de 1935, assistir a uma limitação de seu uso político e a abertura de investigações sobre abusos na eleição anterior não foram limitações secundárias do poder político de um governante autoritário como Flores da Cunha. Todavia, em um processo de isolamento político, ele não tinha muitas opções.

Mas a unificação da política estadual, após um ano de marchas e contramarchas, não foi um pacto consistente. As afirmações de Raul Pilla exemplificam bem essa questão.

\footnotetext{
Que sucedeu então? Os novos secretários não tinham ainda tomado posse dos cargos e já a imprensa oficial e oficiosa ameaçava céus e terras com o Rio Grande unido. O pacto mostrava desde logo o seu verdadeiro aspecto: era um simples cálculo do caudilho [Flores da Cunha]. E já das palavras se passava aos atos. Desde então não cessou a compra de armamentos e organização de corpos provisórios, tudo isso sem, já não digo aprovação, mas sequer conhecimento do representante do Partido Libertador. (PILLA apud RANGEL, 2001, p. 196).
}

Até mesmo no PRL o acordo não foi consensual. Cerca de uma semana após o acordo, o deputado estadual José Loureiro da Silva declarou: “[...] o acordo foi recebido friamente pelo nosso partido (PRL) em certos meios, sobretudo nas classes conservadoras, com certo grau de ironia" (SILVA apud ABREU, 2007, p. 110). Enquanto isso, a FUG mantinha uma via de contato aberta com Getúlio Vargas, que procura criar insistentemente um dissídio na unificação partidária rio-grandense e, por intermédio de Benjamin Vargas, irmão do presidente e deputado estadual do PRL, iniciou a criação de uma cisão interna no partido de Flores da Cunha.

Batista Lusardo, libertador, em março de 1936 é convidado para um churrasco de um amigo com a presença de Getúlio que, sabendo da inimizade entre o governador gaúcho e deputado frenteunista, declara: "Eis a sua oportunidade. Foi ele quem lhe fez tudo aquilo [o exílio de 1932]. Não eu!” (CARNEIRO, 1978, p 195-197). Quando João Neves da Fontoura, líder das oposições coligadas pede desligamento do posto, seria Batista Lusardo quem se tornaria chefe do bloco na Câmara Federal, mesmo que por pouco tempo, pois, semanas depois, a FUG se desligaria por completo do bloco de oposição, alinhando-se gradualmente com a política varguista. Todavia, o enredamento da FUG não foi visto com bons olhos por todos os frenteunistas, como Lindolfo Collor, 
que, em telegrama, dizia não aceitar uma aliança com Getúlio. O presidente também sabia do cerco em que o governador estava tentando levá-lo. A formação de um secretariado no estado, um 'parlamentarismo à gaúcha', somava à bancada florista, frenteunista mais a oposição paulista, os republicanos mineiros e os progressistas cariocas. Juntos, poderiam controlar o legislativo federal e limitar o poder das mãos de Vargas (RANGEL, 2007).

Não obstante, em nível federal, os preparativos para cercar Flores da Cunha estavam a todo o vapor. De acordo com Adriana Iop Bellintani, pouco antes da primeira crise do Modus Vivendi, Flores da Cunha alegou ter descoberto uma conspiração armada contra o seu governo. Por meio dessa descoberta, inicia uma espécie de corrida armamentista, equipando e mobilizando os seus provisórios, articulando planos militares ofensivos e defensivos contra o governo central com seus 14 mil provisórios, e se aliou com líderes militares de outros estados. Essa questão foi vista com muita animosidade por Vargas, afinal, os provisórios se constituiriam como um verdadeiro entrave para o processo de fechamento político (BELLINTANI, 2002).

Anular Flores da Cunha era o passo mais importante para a derrubada do regime vigente, e um avanço nesse sentido foi feito por Getúlio Vargas: o rompimento da união política estadual em outubro de 1936, cerca de dez meses após o acordo. A saída do PL e do PRR da composição do governo estadual, por um desentendimento em torno da eleição para vice-presidente da Assembleia estadual e de um aditivo às cláusulas do acordo de 17 de janeiro, resultou na intensificação do isolamento do governador gaúcho, já que no próprio PRL uma ala dissidente, que se colocaria como varguista e antiflorista, apoiou a FUG e passou a fazer oposição ao governador. Desse modo, corroboramos a assertiva de René E. Gertz (2005), quando ele afirmou que o cerco do Catete ao governador veio em duas frentes: uma política, a outra militar.

Por sinal, essa crise no seio do PRL estaria em sua gênese: sendo um partido criado às pressas, de improviso, para amparar àqueles que ficaram ao lado do então governo provisório e interventoria estadual, teriam em comum somente o fato de divergirem da FUG e apoiarem Getúlio Vargas e Flores da Cunha. A partir do momento em que os dois passam a se distanciar, e Flores da Cunha passou a se alinhar com a Frente Única Gaúcha, que liderava o bloco de oposição ao presidente em nível nacional, o crash do PRL em duas alas, uma varguista e antiflorista, e outra florista e antivarguista, era processo quase natural. 
Contudo, os partidos frenteunistas também sofreram abalos. Os pró-Flores da Cunha do PL fundaram a União Democrática Nacional (UDN) ${ }^{8}$, encabeçada por Bruno de Mendonça Lima, enquanto uma ala, autodenominada de "Ação Libertadora", rompe com a decisão do PL em apoiar José Américo de Almeida nas eleições presidenciais e fica ao lado de Armando Salles. Já no PRR, apesar de Lindolfo Collor pedir demissão da secretaria que ocupava junto a Raul Pilla no Modus Vivendi, acaba fundando o Partido Republicano Castilhista (PRC), também ao lado do governador.

O cerco político em âmbito regional tem vínculos com as articulações nacionais para a eleição à presidência da república. Flores da Cunha decide apoiar Armando de Salles Oliveira, antigo adversário em 1932, contra José Américo de Almeida, que se lançaria como candidato da situação um pouco mais tarde. Segundo Luciano Aronne de Abreu (2007):

\begin{abstract}
Após um breve período de oscilação, Flores da Cunha decidiu-se por apoiar o nome de Armando de Sales [sic] - que recebeu também o apoio das oposições da Bahia e de Pernambuco - como candidato à sucessão de Vargas. Ainda que tenham sido adversários em 1932, o que levou Flores e Sales [sic] a se unirem em 1937 foi a preocupação comum de setores das oligarquias gaúcha e paulista com a perda de seu poder político [...] Como consequiência [sic] direta do apoio de Flores a Sales [sic], em nível nacional acelerou-se a aproximação da FUG com Getúlio Vargas e, no plano regional, precipitou-se a dissidência da aliança governista e do próprio PRL, levando o governador a perder sua maioria parlamentar. Estes acontecimentos vêm a confirmar aquilo que, desde fevereiro de 1936, J. Macedo já havia observado em carta ao Presidente: 'É voz geral, é comum ouvir-se: se esta união (o 'modus vivendi') é para ir contra o Getúlio podem ficar certos os chefes políticos que ficarão sós'. (ARONNE DE ABREU, 2007, p. 119-120).
\end{abstract}

Getúlio procurou abrigar e assegurar o apoio que os grupos dissidentes no Rio Grande do Sul tinham lhe dado. Em carta de janeiro de 1937 para Oswaldo Aranha, durante a visita desse ao Rio Grande do Sul, Vargas afirmou:

\begin{abstract}
Sobre tuas conversas ai, ignoro o que pretende ou deseja governador. Não penso fazer-lhe qualquer proposta alem do que conversamos aqui, pois, não confio nele e tive que, para defender-me dele, estabelecer ligações que não posso abandonar. Meus telegramas posteriores a ti, apenas para teu conhecimento como base para exame tuas conversações, nunca como opinião minha e menos ainda iniciativa qualquer entendimento. Este só poderá ser feito como troca de ideias entre ambos, pendente meu conhecimento e aprovação posterior. Comprehendes delicadeza situação de quem sempre se recusou entendimentos com adversários enquanto tive apoio dele, mas tive de recebel-os depois que ele pretendeu fazel-os seus instrumentos para atacarme. Não posso agora entregar a ele os elementos que me apoiaram no
\end{abstract}

\footnotetext{
${ }^{8}$ Nada tem a ver com a UDN do pós-1945. Bruno de Mendonça Lima, nesse período, seria integrado ao Partido Socialista Brasileiro, onde concorreria a governador do estado (1945) e senador (1950), ficando com a mais baixa votação entre os concorrentes nos dois sufrágios.
} 
momento difícil. como não abandonarei também esse guapo grupo de rapazes do partido liberal que constituem o melhor de sua organização. (FUNDAÇÃO GETÚLIO VARGAS, 1937). ${ }^{9}$

Podemos, com o telegrama acima, aferir que Getúlio, além de se preocupar em manter a nova situação política no estado, que lhe era favorável, também teve que justificar a aliança com figuras que tentaram derrubar o governo por meio das armas. Vargas também tenta "blindar" Aranha contra as investidas de Flores da Cunha, que poderia acarretar na adesão desse ao bloco florista.

Com o cerco político praticamente completo, restava ao presidente derrubar o último baluarte de sustentação do governador, e o mais complicado: os corpos provisórios e o poder militar do estado. Desde setembro de 1935, quando sua relação com o governo federal se tornara mais hostil, Flores da Cunha procurou demonstrar e fortalecer o poderio militar que o cercava. A primeira grande demonstração ocorreu em outubro, quando Flores declarou que o Rio Grande do Sul faria tudo para normalizar a vida política do país, e tentaria retirar da cabeça de alguns a ideia de se implantar uma nova ditadura, e que, se isso ocorresse, o Rio Grande do Sul se levantaria em armas contra a medida. Ao concluir sua fala, explanou: “[...] quero que a nação saiba que eu lutaria até a última gota do meu sangue!” (MUSEU DE COMUNICAÇÃO HIPÓLITO JOSÉ DA COSTA, 10/10/1935, p. 6). ${ }^{10}$

De uma ameaça verbal, não demorou para uma demonstração real ocorrer: ao saber do levante comunista em novembro, Flores da Cunha rapidamente mobilizou vinte mil homens e enviou a Vargas um telegrama disponibilizando seus soldados. Apesar de negada a ajuda pelo presidente, a demonstração de força dos provisórios alertou Vargas sobre a força bélica que o Rio Grande do Sul possuía, enquanto o presidente tomava medidas extremas do Congresso Nacional, que permitiram a declaração do Estado de Sítio e encaminhar o Estado de Guerra (CORTES, 2007). Além disso, o levante comunista propiciaria com que a Lei de Segurança Nacional, aprovada em abril de 1935, pudesse ser usada com toda a intensidade possível no processo de repressão e centralização política. Se os comunistas propunham "todo o poder a Aliança Nacional Libertadora (ANL)", o levante, ironicamente, foi um "prato cheio" para que fosse dado "todo o poder ao Palácio do Catete". Esse processo de centralização também

\footnotetext{
${ }^{9}$ FUNDAÇÃO GETÚLIO VARGAS. CPDOC: AGV 37.01.04/1; Rio de janeiro, 04/01/1937. $1 \mathrm{f}$.

${ }^{10}$ MUSEU DE COMUNICAÇÃO HIPÓLITO JOSÉ DA COSTA. Setor de imprensa. Correio do Povo, Porto Alegre, 10/10/1935. p. 6.
} 
influiu para fortalecer Getúlio Vargas contra Flores da Cunha, sendo que o segundo, contraditoriamente, tinha apoiado ${ }^{11}$ a promulgação da Lei de Segurança Nacional (LSN) naquele momento e, agora, defendia sua aplicação com exceção aos estados que não registraram perturbações, livrando o Rio Grande do Sul da medida.

Em suas memórias, Góis Monteiro narra a luta por aumento do soldo entre militares em 1935, que, em um grupo oficial apoiado por Flores da Cunha, ocorreu a insurgência contra Góis, então Ministro da Guerra. Com esse ocorrido, Góis não pode permanecer no Ministério, pedindo demissão do cargo por quebra da disciplina militar. $\mathrm{Na}$ hora da escolha do novo nome, o presidente teria consultado Góis Monteiro para a escolha do novo nome e dito: "[...] êle [Flores da Cunha] me pagará o que fêz!" (COUTINHO, 1956, p. 265). Já em 1936, em agosto, relatou ser chamado ao Catete por Getúlio. Nesse encontro, Vargas sabendo da animosidade entre Flores e Góis, lembrou ao segundo que o primeiro ainda mantinha os corpos provisórios. A isso, deixemos ao próprio Góis relatar:

\begin{abstract}
Disse-lhe, então, que isso era uma anomalia, um absurdo, e que se devia começar a ação por eliminar êsse estado de coisas, competindo ao Exército fazê-lo, e que, apesar de saber que sempre aparecem os trânsfugas e os coveiros da própria classe militar a que pertencem, eu me encarregaria de levantar o Exército contra uma aberração que não podia coexistir com a permanência da Fôrças Armadas e as atribuições que a constituição lhe confere. (COUTINHO, 1956, p. 282).
\end{abstract}

\footnotetext{
${ }^{11}$ De acordo com Derocina Campos, Flores da Cunha foi contrário à Lei de Segurança Nacional. O que é uma meia-verdade: mesmo que não tenhamos encontrado declarações dele nos momentos em que se debateu a LSN, percebemos nos jornais do PRL a defesa do projeto e ataques a Frente Única Gaúcha que se lançava em uma cruzada contra essa lei, ou seja, por meio dos periódicos floristas, podemos afirmar que Flores da Cunha também defendeu a aprovação da LSN, ainda em uma conjuntura de aliança com Getúlio Vargas. Posteriormente, Flores da Cunha faria ressalvas em sua aplicação, a partir de novembro, sendo contra a extensão do Estado de Sítio em todo o país, mas nem por isso se posicionou contra a lei de forma geral. O que Derocina Campos fez foi aplicar declarações de Flores da Cunha e aliados (como de Quim César, realizada em outubro de 1936), inseridos em um contexto distinto, para justificar que ele foi 'sempre contra', o que não é verdadeiro. Como ela não cita declarações de Flores da Cunha sobre a lei, acreditamos que ela, assim como nós, também não encontrou falas e telegramas partidos do interventor contemporâneos ao projeto de lei. Também vacila em alguns anacronismos, quando afirma que Flores da Cunha não se intimidou com a lei (que foi proposta em janeiro de 1935, mas aprovada em 4 de abril, apesar da autora afirmar que a lei foi aprovada em janeiro) realizando, segundo ela, práticas ilegais, como o desmembramento de Passo Fundo, que na verdade ocorreu em 18 de dezembro de 1934, antes da validade da lei, e precisou da decretação do governo federal, além de mencionar fraudes eleitorais em outubro de 1934, como se essas pudessem ser enquadradas na lei de forma retroativa. Suas afirmações podem ser vistas em Sosa (2001, p. 43-55). Afirmações semelhantes que isolaram o oposicionismo de Flores da Cunha à LSN de novembro em diante, e, dessa forma, não perceberam a mudança de posicionamento dele em relação a essa lei, nem que sua contrariedade era com a aplicação no Rio Grande do Sul, mas reconhecia a necessidade de ela vigorar nos demais estados, podem ser vistas em Bellintani (2002, p. 42-51). O posicionamento dos jornais do PRL pode ser visto em A Federação, 05/04/1935 e 24/04/1935 e Diário Liberal transcrito por Trindade (1980, p. 237).
} 
A partir desse momento, Vargas traz a cena novamente o maior rival de Flores da Cunha no exército e começa a intensificar, em parceria com ele, o cerco militar ao Rio Grande do Sul. A ameaça dos provisórios começa a ser desmantelada por Getúlio de maneira cautelosa, sendo o primeiro passo o encaminhamento de um estado politicamente dividido. Afinal, Vargas conhecia o que o Rio Grande do Sul unido poderia fazer no campo militar. As atividades dos provisórios gaúchos foram cuidadas de perto por aliados varguistas no Rio Grande do Sul. Em novembro de 1936, o General Lucio Esteves comunicou Walder Sarmanho sobre reuniões de provisórios em Marcelino Ramos, Passo Fundo e Santa Maria. Também alertava para seus usos na construção de estradas e rodagens. Já em outro telegrama, o alerta é dado para uma aliança armada Rio Grande-São Paulo, entre Armando Salles e Flores da Cunha. Desvios por parte de militares no exército no Rio Grande do Sul também não ficaram em desatento. Manuel Olívio Pires, chefe do posto aduaneiro de Santo Angelo e "extremado político partidário" foi acusado de aliciar membros de provisórios da cidade para atacar a rede de segurança da guarnição federal, sendo solicitado seu desligamento (AGV-CPDOC, 1936). ${ }^{12}$ Essa prática fora adotada todas as vezes que um elemento do exército era suspeito de possuir algum tipo de ligação com Flores da Cunha, procurando anular os opositores a Vargas nas guarnições federais que preparavam, nesse momento, uma intervenção federal no estado.

Posteriormente, em maio, Góis retorna ao Rio Grande do Sul sob virulentos ataques e denúncias na Assembleia Legislativa, no Congresso Nacional e pela imprensa, denunciando a intervenção no estado gaúcho. Com sua visita, a preparação para interferir militarmente no estado estava sendo dada, com o movimento de tropas de reforço para São Paulo, Paraná e Santa Catarina, sendo transportadas por via marítima e terrestre em direção à fronteira norte do Rio Grande do Sul. Quando se preparavam as tropas para convergir sobre Porto Alegre e os pontos vitais do estado, Góis Monteiro foi chamado por Dutra, devido aos ataques que sofria por aquela operação, que padecia da rejeição de importantes oficiais do Exército (COUTINHO, 1956).

Por aquele momento, fora abortado o movimento contra o Rio Grande do Sul. Com o cerco formado nos campos político e militar, Flores da Cunha estava isolado. Sem apoio externo, mantinha algum tipo de contato com Armando Salles e alguns poucos governadores de oposição (ABREU, 2007). Flores da Cunha não tinha saída

\footnotetext{
${ }^{12}$ FUNDAÇÃO GETÚLIO VARGAS. CPDOC: AGV 36.11.00. Rio de Janeiro. 11/1936. 2 f.
} 
com o contexto criado. Isolado e sem perspectivas, estava pronto para tomar o "xeque mate" de Getúlio Vargas.

Claro que as ligações entre exército e política não ficaram distantes. Por exemplo, Maurício Cardoso, em uma conjuntura política difícil para Flores da Cunha, que possuía a maioria de um voto apenas na Assembleia Legislativa, propôs a Getúlio Vargas que os deputados oposicionistas se declarassem coagidos e incapacitados de exercerem seus mandatos, refugiando-se em um quartel do Exército em Porto Alegre, de onde pediriam a intervenção federal no estado. Essa medida, vista até com certa simpatia por Getúlio, foi rechaçada por Góis Monteiro. O que os deputados oposicionistas planejavam era aproveitar o clima hostil que os debates na Assembleia Legislativa proporcionavam, já que os trabalhos foram inundados com os deputados armados com revólveres na cintura e com capangas contratados por Flores da Cunha dentro e fora do prédio, ao passo que a oposição revidou na mesma moeda, contratando seus próprios homens encabeçados pelo controverso Gregório Fortunato. Maurício Cardoso, em 15 de setembro de 1937, e com respaldo de Vargas, liderou até mesmo um movimento a favor do impeachment de Flores da Cunha, que naquela conjuntura possuía a minoria de um voto. Flores da Cunha, coagindo um deputado classista a renunciar, conseguiu reverter a situação, agora com um voto de diferença a seu favor (CORTES, 2007).

O parlamento, por sinal, colocou Flores da Cunha em duas situações excepcionais: foi o primeiro da história política do estado a ter minoria no legislativo, que não era mais uma Assembleia Orçamentária ${ }^{13}$ como no período castilhista-borgista, ou seja, tinha mais peso político, e o primeiro chefe da administração estadual a sofrer um processo de impeachment.

Falhada a cartada de Maurício Cardoso, a derrubada de Flores da Cunha veio com um documento, entregue por General Daltro Filho, que solicitava a federalização da Brigada Militar, solapando sua principal força naquele momento. Consultando o Secretariado e o desembargador André da Rocha, procurou brechas legais para impedir que a passagem de comando da milícia estadual fosse efetuada. Convocando a bancada classista e liberal, Flores da Cunha colocou em pauta duas opções: resistir ou renunciar, sendo a segunda opção escolhida por ampla maioria, o que ocorreu em 17 de outubro,

\footnotetext{
${ }^{13}$ Sobre essa questão consultar: Rouston Júnior (2014).
} 
poucos dias antes da decretação do Estado Novo, agora livre da maior resistência ao golpe (SCHNEIDER, 1981).

Flores renuncia para não assinar a entrega da Brigada Militar ao Palácio do Catete, medida que denotou mais um "orgulho" do que resultados práticos efetivos, já que não evitou a federalização da polícia estadual. No dia seguinte ao seu afastamento, ele tentou manobrar um nome de consenso dentro do PRL para a Assembleia Legislativa eleger como novo governador nos termos da constituição de 15 de abril de 1935, tentativa ocorrida sob Antunes Maciel Jr., mas Vargas acabou com essa possibilidade ao decretar a intervenção federal no estado, nomeando interventor o comandante da III Região Militar, General Daltro Filho. Ou, nas palavras de Eliane Colussi (1996), é possível dizer que Vargas antecipou o Estado Novo no Rio Grande do Sul quase um mês.

Dessa forma, não coube a Flores da Cunha outra opção a não ser dirigir-se para Santana do Livramento, sua terra natal e reduto político para, no dia seguinte, seguir a Rivera, onde viveria exilado até 1942 com seus passos vigiados por Batista Lusardo, que seria o embaixador brasileiro naquele país com essa finalidade. Logo em seguida ao seu retorno, passou 9 meses na prisão por comprar ilegalmente armamentos no exterior, quando foi esteve no controle da administração estadual (BELLINTANI, 2002).

\section{Considerações finais}

Procuramos, neste artigo, elucidar algumas questões relacionadas ao embate entre Flores da Cunha e Getúlio Vargas, buscando compreender a disputa entre ambos em um jogo de rixa de poder em que um visava anular o outro, mas que acabou com o isolamento político de Flores da Cunha, a ponto de solapar do governador até mesmo a possibilidade de avançar militarmente contra as investidas de Vargas. Nesse processo, teve papel importante a Frente Única Gaúcha, opositora a Vargas, que, em um primeiro momento, aliou-se a Flores da Cunha, mas nunca fechou diálogos com o presidente que, outrora, pegou em armas para tentar destituir. Foi com Getúlio que a FUG pendeu, sendo decisiva junto à Dissidência Liberal, uma ala varguista do PRL e apoiada pelo presidente para isolar o governador.

Nesse processo, assistimos uma longa negociação e a interferência direta de Vargas na política estadual propendendo a desequilibrar o governador, que se lançava em feroz oposição ao governo central. Entretanto, é importante ressaltar que as 


\section{Rafael Saraiva Lapuente}

manobras políticas são consequência, também, de uma nova conjuntura, com o gradual fortalecimento do poder central em detrimento da autonomia regional, afrontando a tradicional estrutura política do período 1889-1930.

À guisa de conclusão, procuramos contribuir com a historiografia de forma a elucidar algumas particularidades que antecederam a decretação do Estado Novo, bem como sua articulação e a derrubada de políticos que se posicionaram contrários a sua implantação, conhecendo, também, uma multiplicidade de atores envolvidos por meio de um ângulo regional, assim como também contribuir para a produção acadêmica sobre os anos 1930-1937 no Rio Grande do Sul, ainda carente de maiores trabalhos. 


\section{REFERÊNCIAS}

\section{Fontes primárias}

BIBLIOTECA NACIONAL. Hemeroteca Digital. A generosidade em função da paz, A Federação, 24.05.1933, p.1.

BRASIL. Congresso Nacional. Câmara dos Deputados. Diário da Câmara dos Deputados. Discurso do deputado Flores da Cunha. Rio de Janeiro. Ano VIII, n. 69, 11.04.1953, $\quad$ p. 2639. Disponível em: <http://imagem.camara.gov.br/Imagem/d/pdf/DCD11ABR1953.pdf\#page=>. Acesso em 25.07.2015.

FUNDAÇÃO GETÚlio VARGAS. CPDOC: AGV 37.01.04/1. Rio de janeiro, 04/01/1937. $1 \mathrm{f}$.

FUNDAÇÃO GETÚliO VARGAS. CPDOC: AGV 36.11.00. Rio de Janeiro. 11/1936 $2 \mathrm{f}$.

MUSEU DE COMUNICAÇÃO HIPÓLITO JOSÉ DA COSTA. Setor de imprensa. Correio do Povo, Porto Alegre, 10/10/1935. p. 6.

PARTIDO REPUBLICANO LIBERAL. O Partido Republicano Liberal e seu programa. Porto Alegre: Oficinas gráficas da Livraria do Globo, 1933.

\section{Fontes secundárias}

ABREU, Luciano Aronne de. Um olhar regional sobre o Estado Novo. Porto Alegre: EDIPUCRS, 2007.

BAQUERO, Marcello; PRÁ, Jussara Reis. A Democracia Brasileira e a Cultura Política no Rio Grande do Sul. Porto Alegre: Editora da Universidade Federal do Rio Grande do Sul, 2007.

BELlintani, Adriana Iop. Conspiração contra o Estado Novo. Porto Alegre: EDIPUCRS, 2002.

BERSTEIN, Serge. A cultura política. In: RIOUX, Jean Pierre. SIRINELLI, JeanFrançois. Para uma história cultural. Lisboa: Estampa, 1998.

BERSTEIN, Serge. Os partidos. In: RÉMOND, René (Org.). Por uma história política. Rio de Janeiro: FGV, 2003.

CAMPOS, Derocina Alves. Federalismo versus centralização: a década de 1930 no Rio Grande do Sul. Rio Grande: Fundação Universidade Federal do Rio Grande, 2001.

CARNEIRO, Glauco. Lusardo, o último caudilho. Rio de Janeiro: Nova Fronteira, 1978. 
COLUSSI, Eliane Lucia. Estado Novo e municipalismo gaúcho. Passo Fundo: Ediupf, 1996.

CORTES, Carlos E. Política gaúcha (1930-1964). Porto Alegre: EDIPUCRS, 2007.

COUTINHO, Lourival. O General Góes depõe... Rio de Janeiro: Livraria editora Coelho Branco, 1956.

ELÍBIO JR, Antônio Manuel. A construção da liderança política de Flores da Cunha: Governo, história e política (1930-1937). 2006. Tese (Doutorado em História) Universidade Estadual de Campinas, Programa de Pós-graduação em História, Campinas, 2006.

GERTZ, René Ernaini. O Estado Novo no Rio Grande do Sul. Passo Fundo: UPF Editora, 2005.

LAPUENTE, Rafael Saraiva. Os políticos gaúchos exilados: conspirações contra os governos Getúlio Vargas e Flores da Cunha (1932-1934). In: HEINSFELD, Adelar; RECKZIEGEL, Ana Maria Setti (Org.). Anais do III Congresso Internacional de História Regional. Passo Fundo: UPF, 2015.

MOTTA, Rodrigo Patto Sá. Culturas políticas na história: Novos estudos. Belo Horizonte: Traço fino, 2014.

MOTTA, Rodrigo Patto Sá. Introdução a História dos partidos políticos brasileiros. Belo Horizonte: Editora UFMG, 1999.

RANGEL, Carlos Roberto da Rosa. Crime e Castigo: conflitos políticos no Rio Grande do Sul (1928-1938). Passo Fundo: Editora UPF, 2001.

RÉMOND, René. Do político. In: RÉMOND, René (Org.). Por uma história política. Rio de Janeiro: FGV, 2003.

ROUSTON JÚNIOR, Eduardo. O Rio Grande do Sul republicano sob a ótica parlamentar da oposição federalista (1913-1924). Porto Alegre: EDIPUCRS, 2014.

SCHNEIDER, Regina Portella. Flores da Cunha: O último gaúcho legendário. Porto Alegre: Martins Livreiro, 1981.

SOUZA, Maria do Carmo Campello de. Estado e partidos políticos no Brasil (19301964). São Paulo: Alfa-Ômega, 1990.

TRINDADE, Hélgio (Org.). Revolução de 30: Partidos e Imprensa partidária no RS. Porto Alegre: L\&PM Editora, 1980.

VARGAS, Getúlio. Diário. vol. I; vol. II. São Paulo: Siciliano; Rio de Janeiro: FGV, 1995. 